\title{
4. GEOCHEMISTRY OF CARBON: DEEP SEA DRILLING PROJECT LEG 40
}

\author{
J.G. Erdman and K.S. Schorno, Phillips Petroleum Company, Bartlesville, Oklahoma
}

\section{INTRODUCTION}

Forty core sections from Sites 361,362 , and $362 \mathrm{~A}$, from the Cape Basin and Walvis Ridge (Figure 1), were received through the JOIDES Organic Geochemistry Advisory Panel. The studied samples represent the full suite of frozen cores taken for organic geochemical study.

All frozen core samples for this study were taken and preserved under the shipboard supervision of Dr. James B. Foresman of this laboratory. The workup procedure for carbon types is shown diagrammatically in Figure 2. The solvents were distilled in glass immediately before use. Each analytical determination was performed in duplicate.

\section{SAMPLING AND STUDY PROCEDURES}

The frozen core samples were split by the senior author at the Scripps Institute of Oceanography. The frozen half sections then were transferred to this laboratory for geochemical characterization. The flat frozen surface of each longitudinal half section was smoothed for description and photographing using an oil-free milling machine and flycutter. The plane surface was warmed sufficiently to eliminate frost. After photographing and descriptions, the samples were maintained frozen until initiation of chemical studies.

Each sample was photographed both in color and black and white and described. Chips of each textural type of lithology were removed for determination of carbonate and organic carbon. The values are provided in Table 1 along with the lithological descriptions.

\section{RESULTS AND DISCUSSION}

Numerical data generated for the samples are provided in Tables 2-5. In Table 2 the average carbonate and organic carbon content of the core setions and the proportion of the organic fraction consisting of lipid and kerogen are tabulated against geologic age and subbottom depth. Lipid is defined as organic matter soluble in methylene chloride. Organic matter insoluble in methylene chloride is defined as kerogen. Table 3 provides the carbon isotoic composition of the lipid and kerogen fractions and the difference between these two values. Finally, Tables 4 and 5 provide (a) the $\mathrm{C}, \mathrm{H}, \mathrm{N}, \mathrm{S}$, and $\mathrm{O}$ content of the lipid fraction and (b) the concentrations of ion exchangeable ammonia nitrogen and total nitrogen. The latter consists of organic nitrogen, ion exchangeable ammonia nitrogen, and ammonium nitrogen locked in the clay lattice in the dehydrated rock samples. Due to analytical requirements, the elemental analyses could be carried out only for those samples from which a minimum of $40 \mathrm{mg}$ of lipid was obtained. The nitrogen determinations were made by half Kjeldahl (alkaline distillation) and by full Kjeldahl (sulfuric acid digestion followed by alkaline distillation), respectively.

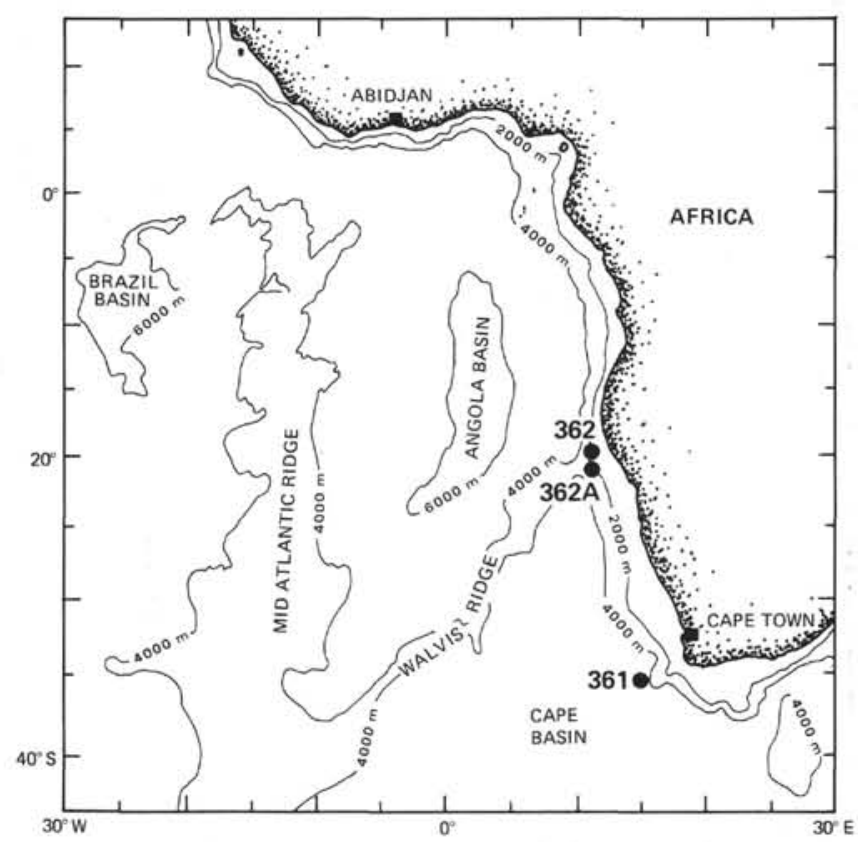

Figure 1. Location of holes from which samples for geochemical study were obtained.

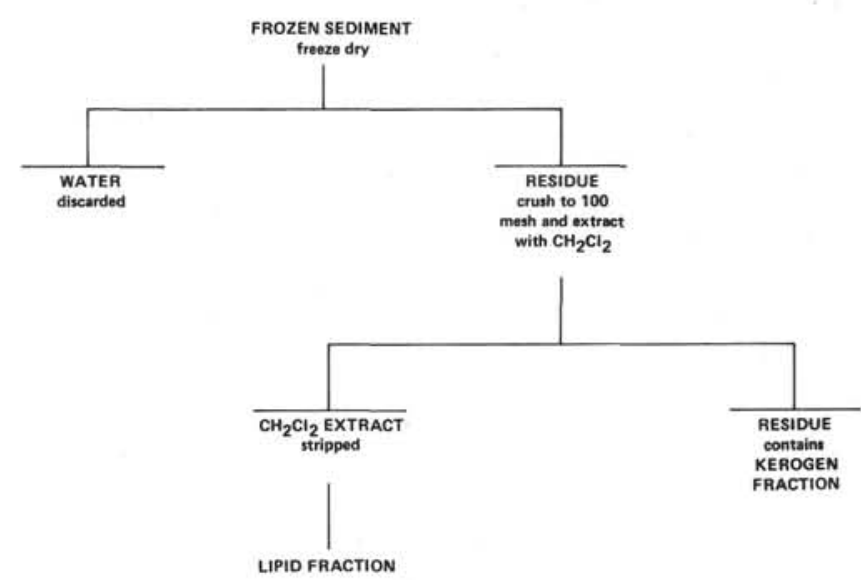

Figure 2. Flow diagram for separation and determination of carbon species. 
TABLE 1

Lithological Descriptions and Carbonate and Organic Carbon Values in Weight Percent for Lithologies in Cores Sections

\begin{tabular}{cl}
\hline $\begin{array}{c}\text { Site- } \\
\text { Core- } \\
\text { Section }\end{array}$ & \\
\hline $361-5-4$ & $\begin{array}{l}\text { Marly nannofossil ooze, light bluish-gray } \\
\text { (5B 7/1), medium bluish-gray (5B 5/1), } \\
\text { and greenish-gray (5G 6/1), irregular laminae } \\
\text { with patches of brownish-gray (5YR 3/1); } \\
\text { scattered pyrite patches and glauconite layers; } \\
\text { heavy minerals include epidote, zircon, tourma- } \\
\text { line, chlorite, and garnet; small silt-sized pock- } \\
\text { ets of quartz; bedding slightly disturbed in } \\
\text { coring }\end{array}$ \\
$361-8-5$ & $\begin{array}{l}\text { Marly nannofossil chalk; very pale orange } \\
\text { (10 YR 8/2). Heavy minerals include chlorite, } \\
\text { zircon, opaques, iron oxide; burrowing; core } \\
\text { essentially homogeneous throughtout }\end{array}$ \\
$361-10-5$ & $\begin{array}{l}\text { Pelagic clay, yellowish-brown (5 YR 4/4), and } \\
\text { dark yellowish-brown (10 YR 4/2), pale to } \\
\text { grayish-green (5 G 6/1) cast in lighter part, red } \\
\text { streaks (10 YR 4/6), around lighter portion; } \\
\text { heavy minerals of epidote, tourmaline, garnet, } \\
\text { and opaques }\end{array}$
\end{tabular}

361-12-4 Pelagic clay, moderate brown (5YR 3/4 to 5 YR $4 / 4$ ), with minor patches of greenish-gray ( $5 \mathrm{G}$ $6 / 1$

\begin{tabular}{ccc}
\multicolumn{2}{c}{ Carbonate As } & Organic \\
Carbon & $\mathrm{CaCO}$ & Carbon \\
(wt $\%)$ & $(\mathrm{wt} \%)$ & $(\mathrm{wt} \%)$
\end{tabular}

$\begin{array}{llll}\text { 1. } & 6.05 & 50.42 & 0.29 \\ \text { 2. } & 3.55 & 29.58 & 0.58 \\ \text { 3. } & 1.85 & 15.42 & 1.06 \\ \text { 4. } & 3.39 & 28.25 & 0.47 \\ \text { 5. } & 1.33 & 11.08 & 0.42 \\ \text { 6. } & 3.68 & 30.67 & 0.41 \\ \text { 7. } & 1.47 & 12.25 & 3.30 \\ & & & \\ & & & \\ \text { 1. } & 9.08 & 75.67 & <0.1 \\ & & & \\ & & & \\ & & & \\ 1 . & <0.1 & <0.83 & <0.1 \\ 2 . & <0.1 & <0.83 & <0.1 \\ 3 . & <0.1 & <0.83 & <0.1\end{array}$

361-23-3 Shale, finely laminated. Black to dark gray $\left(\mathrm{N}_{1}-\mathrm{N}_{3}\right)$, alternating with brownish-gray (5 YR 3/1), layers slightly calcareous, trace of pyrite, heavy minerals include zircon, epidote, and opaques

361-25-3 Shale, medium bluish-gray (5 B 5/1), alternating with dusky red (5 R 3/4) and grayish-red (5 R 4/2) claystone; calcareous, slightly crossbedded laminae

361-27-3 Shale, thinly laminated, lithified, hard, dark to medium dark gray $\left(\mathrm{N}_{3}-\mathrm{N}_{4}\right)$, with darker greenish-black $(5 \mathrm{G} \mathrm{2/1)}$ streaks and some medium bluish-gray (5 B 5/1) cast; clay $62 \%, 33 \%$ silt, trace sand, pyrite laminae, bedding undisturbed by coring process.

361-29-5 Mudstone, greenish-black (5 G 2/1) carbonaceous

$\begin{array}{lllr}\text { 1. } & 0.45 & 3.75 & 3.89 \\ & & & \\ \text { 1. } & 0.38 & 3.16 & 2.59 \\ \text { 2. } & 0.15 & 1.25 & 0.29 \\ \text { 3. } & 0.36 & 3.00 & 56.36\end{array}$

$\begin{array}{lllllr}\text { 361-31-2 } & \text { Sandy mudstone, greenish-black ( GY 2/1) } & 1 . & 0.38 & 3.16 & 2.59 \\ & \text { with lighter layer of medium gray }\left(\mathrm{N}_{5}\right) \text {; } & 2 . & 0.15 & 1.25 & 0.29 \\ & \text { carbonaceous, slightly burrowed; contains feld- } & 3 . & 0.36 & 3.00 & 56.36\end{array}$ spar, traces of mica, heavy minerals, and nannofossils; seam of abundant wood bits at bottom of core (No. 3)

361-34-4 Shale, dark brownish-gray (5 YR 3/1) to dark gray $\left(\mathrm{N}_{3}\right)$, carbonaceous with pyrite laminae and concretions; thinly laminated

361-36-3 Sandy mudstone, dark greenish-gray (5 G 4/1) with greenish-black (5 G 2/1) interbeds; light greenish-gray $(5 \mathrm{G} 6 / 1)$ patch of silt stone (No.6) carbonaceous with abundant plant debris (No. 5), calcareous with pyrite concretions; darker sections primarily are mudstone; silt is mostly quartz with some feldspar, mica, and zeolites

$\begin{array}{rrrr}\text { 1. } & 0.12 & 1.00 & 0.10 \\ \text { 2. } & 0.10 & .83 & 0.13 \\ \text { 3. } & 0.18 & 1.50 & 0.11 \\ \text { 4. } & 0.30 & 2.50 & 0.32 \\ \text { 1. } & 0.17 & 1.42 & 0.56\end{array}$

$\begin{array}{llll}\text { 1. } & 0.22 & 1.83 & 0.19 \\ 2 & 0.71 & 5.92 & 0.25\end{array}$

$\begin{array}{llll}\text { 3. } & 0.71 & 5.92 & 0.25\end{array}$

$\begin{array}{llll}\text { 1. } & 0.23 & 1.92 & 0.59\end{array}$

$\begin{array}{llll}\text { 2. } & 0.65 & 5.42 & 0.74\end{array}$

$\begin{array}{llll}\text { 3. } & 2.26 & 18.83 & 0.24\end{array}$

$\begin{array}{lrrr}\text { 4. } & 0.26 & 2.17 & 0.21\end{array}$

$$
\text { (1.42 }
$$

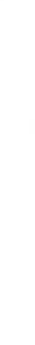


TABLE 1 - Continued

\begin{tabular}{|c|c|c|c|c|c|}
\hline $\begin{array}{l}\text { Site- } \\
\text { Core- } \\
\text { Section }\end{array}$ & & & $\begin{array}{l}\text { Carbon } \\
\text { Carbon } \\
(w t \%)\end{array}$ & $\begin{array}{l}\text { ate } \mathrm{As} \\
\mathrm{CaCO} \\
(\mathrm{wt} \%)\end{array}$ & $\begin{array}{l}\text { Organic } \\
\text { Carbon } \\
\text { (wt } \%)\end{array}$ \\
\hline $361-38-2$ & $\begin{array}{l}\text { Sandy mudstone, greenish-gray (5 G 2/1) } \\
\text { homogeneous, fissile; carbonaceous and } \\
\text { calcareous }\end{array}$ & 1. & 1.37 & 11.42 & 2.23 \\
\hline $36-140-3$ & $\begin{array}{l}\text { Shale, greenish-black ( } 5 \text { G } 2 / 1 \text { ), carbonaceous, } \\
\text { slightly calcareous, thinly laminated }\end{array}$ & & & & \\
\hline $361-42-0$ & $\begin{array}{l}\text { Silty shale, dark brownish-gray ( } 5 \text { YR } 3 / 1 \text { ), } \\
\text { carbonaceous, } 65 \% \text { clay, } 30 \% \text { quartz, trace } \\
\text { feldspar, mica, pyrite, plant debris }\end{array}$ & 1. & 0.24 & 2.0 & 2.73 \\
\hline $361-44-2$ & $\begin{array}{l}\text { Shale, black }\left(\mathrm{N}_{1}-\mathrm{N}_{2}\right) \text {, carbonaceous, } 15 \% \text { silt, } \\
\text { traces of zircon and tourmaline, contains plant } \\
\text { debris (No. } 2) \text {; white flecks are detrital clay }\end{array}$ & $\begin{array}{l}1 . \\
2 .\end{array}$ & $\begin{array}{r}0.14 \\
34.38\end{array}$ & $\begin{array}{r}1.17 \\
>1.00\end{array}$ & $\begin{array}{l}0.06 \\
4.82\end{array}$ \\
\hline $362-1-5$ & $\begin{array}{l}\text { Diatomaceous nanno ooze, olive-gray ( } 5 \text { Y } 3 / 2 \text { ) } \\
\text { with disturbed swirl in lower part moderate } \\
\text { olive-brown ( } 5 \text { Y } 4 / 4) \text {, calcareous, minor con- } \\
\text { stituents include radiolarians, silicoflagellates, } \\
\text { quartz, mica, pyrite, and traces of tourmaline, } \\
\text { epidote and opalite; petroliferous odor emanating } \\
\text { from core }\end{array}$ & 1. & 5.20 & 43.33 & 3.51 \\
\hline $362-3-4$ & $\begin{array}{l}\text { Marly diatomaceous nanno ooze, light olive- } \\
\text { brown (5Y } 4 / 3 \text { to } 4 \text { Y } 4 / 2) \text {, carbonaceous, } \\
30 \%-40 \% \text { calcareous nannofossils, } 30 \%-35 \% \\
\text { clay, } 15 \%-20 \% \text { diatoms, } 1 \%-2 \% \text { foraminifera; } \\
\text { traces of radiolarians, silicoflagellates, quartz, } \\
\text { pyrite, and tourmaline; strongly deformed by } \\
\text { drilling; Petroliferous odor emanating from } \\
\text { freshly cut core }\end{array}$ & $\begin{array}{l}1 . \\
2 .\end{array}$ & $\begin{array}{l}0.70 \\
3.73\end{array}$ & $\begin{array}{r}5.83 \\
31.08\end{array}$ & $\begin{array}{l}4.79 \\
5.57\end{array}$ \\
\hline $362-5-4$ & $\begin{array}{l}\text { Diatomaceous nanno ooze, olive-gray ( } 5 \mathrm{Y} 3 / 2) \text {; } \\
\text { richly carbonaceous, calcareous, } 70 \% \text { clay, } \\
\text { silty; contains Radiolaria, siliceous spicules, } \\
\text { silicoflagellates, and traces of pyrite, mica, and } \\
\text { dolomite rhombs; distortion of bedding caused } \\
\text { by coring; petroliferous od or noted emanating } \\
\text { from core }\end{array}$ & $\begin{array}{l}1 . \\
2 . \\
3 . \\
4 .\end{array}$ & $\begin{array}{l}1.81 \\
4.75 \\
2.68 \\
2.41\end{array}$ & $\begin{array}{l}15.08 \\
39.58 \\
22.33 \\
20.08\end{array}$ & $\begin{array}{l}7.24 \\
5.32 \\
4.84 \\
6.56\end{array}$ \\
\hline $362-7-5$ & $\begin{array}{l}\text { Diatomaceous nanno ooze, olive-gray }(5 Y 3 / 2) \\
\text { with light olive-gray }(5 \mathrm{Y} 5 / 2) \text { interpenetrated } \\
\text { due to deformation in drilling, highly carbon- } \\
\text { aceous; calcareous, } 80 \% \text { clay, silty; contains } \\
\text { forams, Radiolaria, siliceous spicules, trace of } \\
\text { pyrite, epidote and tourmaline; gas cracks, petro- } \\
\text { liferous odor noted }\end{array}$ & 1. & $\begin{array}{l}5.36 \\
2.51\end{array}$ & $\begin{array}{l}44.67 \\
20.92\end{array}$ & $\begin{array}{l}2.50 \\
5.21\end{array}$ \\
\hline $362-9-5$ & $\begin{array}{l}\text { Marly diatomaceous nanno ooze, olive-gray } \\
\text { (5Y 4/2), yellowish-gray inclusions ( } 5 \text { Y } 7 / 2) \\
\text { carbonaceous and calcareous; also contains } \\
\text { Braarudosphaera, coccospheres, and forams, } \\
\text { up to } 3 \% \text { pyrite, } 80 \% \text { clay, } 15 \%-20 \% \text { silt; cracks } \\
\text { or partings partly due to expansion caused by } \\
\text { gas; core shows results of friction and drag } \\
\text { along side of core barrel }\end{array}$ & 1. & $\begin{array}{l}6.65 \\
5.84\end{array}$ & $\begin{array}{l}55.42 \\
48.67\end{array}$ & $\begin{array}{l}2.54 \\
3.45\end{array}$ \\
\hline $362-11-5$ & $\begin{array}{l}\text { Marly nannoplankton ooze, dominantly olive- } \\
\text { gray ( } 5 \mathrm{Y} 4 / 2 \text { ) with olive ( } 5 \mathrm{Y} 4 / 3 \text { ) mottling } \\
\text { carbonaceous; composed of } 50 \%-60 \% \text { cal- } \\
\text { careous nannofossils, and } 25 \%-30 \% \text { clay } \\
\text { minerals; contains foraminifera, diatoms, with } \\
\text { minor amounts of Radiolaria, sponge spicules, } \\
\text { and traces of pyrite, spidote, and chlorite, } \\
\text { petroliferous odor noted from freshly cut core }\end{array}$ & 1. & 6.03 & 50.25 & 2.80 \\
\hline $362-13-4$ & $\begin{array}{l}\text { Marly diatomaceous nanno ooze, light olive- } \\
\text { brown ( } 5 \text { Y } 4 / 3 \text { to } 5 \text { Y } 4 / 2 \text { ), carbonaceous, } 30 \% \\
-40 \% \text { calcareous nannofossils, } 30 \%-35 \% \text { clay, } \\
15 \%-20 \% \text { diatoms, } 1 \%-2 \% \text { foraminifera, traces } \\
\text { of radiolarians, silicoflagellates, quartz, pyrite, }\end{array}$ & 2. & $\begin{array}{l}5.64 \\
5.38\end{array}$ & $\begin{array}{l}47.00 \\
44.83\end{array}$ & $\begin{array}{l}2.53 \\
2.85\end{array}$ \\
\hline
\end{tabular}


TABLE 1 - Continued

\begin{tabular}{|c|c|c|c|c|c|}
\hline $\begin{array}{l}\text { Site- } \\
\text { Core- } \\
\text { Section }\end{array}$ & & & $\begin{array}{l}\text { Carbona } \\
\text { Carbon } \\
\text { (wt } \% \text { ) }\end{array}$ & $\begin{array}{l}\text { te } \mathrm{As} \\
\mathrm{CaCO} \\
\text { (wt\%) }\end{array}$ & $\begin{array}{c}\text { Organic } \\
\text { Carbon } \\
\text { (wt } \%)\end{array}$ \\
\hline $\begin{array}{c}362-13-4 \\
\text { Cont. }\end{array}$ & $\begin{array}{l}\text { and tourmaline; petroliferous odor } \\
\text { noted from freshly cut core; strongly } \\
\text { deformed by drilling }\end{array}$ & & & & \\
\hline $362-15-5$ & $\begin{array}{l}\text { Marly nannoplankton ooze, olive-gray } \\
\text { (5Y 4/2), carbonaceous and calcareous, } \\
90 \% \text { clay, and } 10 \% \text { silt; contains small } \\
\text { amounts of Radiolaria, siliceous spicules, } \\
\text { and traces of pyrite, quarta, epidote, and } \\
\text { chlorite; homogeneous throughout the } \\
\text { core }\end{array}$ & 1. & 5.95 & 49.58 & 2.16 \\
\hline $362-17-5$ & $\begin{array}{l}\text { Diatomaceous marly nanno ooze, light } \\
\text { olive-brown (5Y 4/2) with small dark yellow- } \\
\text { ish-brown (10 YR 4/2) inclusions; calcareous } \\
\text { nannofossils } 50 \%-70 \% \text {, clay } 15 \%-20 \% \text {, foramin- } \\
\text { ifera, minor amounts of radiolarians, siliceous } \\
\text { spicules, traces of dolomite rhombs, pyrite, } \\
\text { and quartz; clay fraction is mostly illite, as } \\
\text { determined by X-ray diffraction. }\end{array}$ & $\begin{array}{l}1 . \\
2 .\end{array}$ & $\begin{array}{l}7.11 \\
5.82\end{array}$ & $\begin{array}{l}59.25 \\
48.50\end{array}$ & $\begin{array}{l}1.27 \\
2.47\end{array}$ \\
\hline $362-19-5$ & $\begin{array}{l}\text { Marly nannoplankton chalk, olive-gray ( } 5 \text { Y } 6 / 1) \\
\text { inclusions resulting from burrows; composed } \\
\text { mostly of calcareous nannofossils and clay; } \\
\text { contains foraminifera, diatoms, and traces } \\
\text { of pyrite and dolomite rhombs }\end{array}$ & $\begin{array}{l}1 . \\
2 .\end{array}$ & $\begin{array}{l}6.84 \\
7.35\end{array}$ & $\begin{array}{l}57.00 \\
61.25\end{array}$ & $\begin{array}{l}1.58 \\
0.97\end{array}$ \\
\hline $362-21-5$ & $\begin{array}{l}\text { Marly nanno chalk, greenish-gray (5GY 6/1) } \\
\text { homogeneous; composed of } 70 \% \text { calcareous } \\
\text { nannoplankton and } 20 \%-30 \% \text { clay minerals; } \\
\text { contains diatoms, foraminifera, Radiolaria, } \\
\text { pyrite patches throughout and traces of } \\
\text { quartz and tourmaline }\end{array}$ & 1. & 8.64 & 72.00 & 0.70 \\
\hline $362-23-5$ & $\begin{array}{l}\text { Diatomaceous marly nanno chalk, yellowish } \\
\text { olive-gray ( } 5 \text { Y } 6 / 1) \text {, mottled appearance with } \\
\text { darker areas of dusky yellow-green ( } 5 \mathrm{GY} 6 / 2) \\
\text { clay; thin seams of pyrite, trace mica, burrows; } \\
\text { bedding essentially is horizontal and relatively } \\
\text { undisturbed by coring process; thin horizontal } \\
\text { parting is due to expansion caused by gas }\end{array}$ & $\begin{array}{l}1 . \\
2 . \\
3 . \\
4 .\end{array}$ & $\begin{array}{l}8.37 \\
* \\
9.14 \\
8.64\end{array}$ & $\begin{array}{l}69.75 \\
* \\
76.17 \\
72.00\end{array}$ & $\begin{array}{l}1.49 \\
* \\
0.93 \\
0.66\end{array}$ \\
\hline $362-25-5$ & $\begin{array}{l}\text { Marly nanno chalk, light greenish-gray ( } 5 \mathrm{G} 8 / 1) \\
\text { with lighter ( } 5 \mathrm{G} 9 / 1) \text { areas due to burrowing; } \\
\text { contains foraminifera, radiolarians, silicoflag- } \\
\text { ellates, cocospheres, pyrite, } 80 \% \text { clay, } 20 \% \text { silt. }\end{array}$ & $\begin{array}{l}1 . \\
2 . \\
3 .\end{array}$ & $\begin{array}{l}8.50 \\
9.03 \\
6.53\end{array}$ & $\begin{array}{l}70.83 \\
75.25 \\
54.42\end{array}$ & $\begin{array}{l}0.77 \\
0.84 \\
1.14\end{array}$ \\
\hline $362-27-5$ & $\begin{array}{l}\text { Marly nanno chalk, greenish gray ( } 5 \text { GY } 6 / 1 \text { ). } \\
\text { Composed of about } 80 \% \text { clay and over } 15 \% \\
\text { silt. Contains diatoms, foraminifera, radiolar- } \\
\text { ia, and traces of pyrite, quartz, and tourmaline. }\end{array}$ & $\begin{array}{l}1 . \\
2 .\end{array}$ & $\begin{array}{l}3.80 \\
6.57\end{array}$ & $\begin{array}{l}31.67 \\
54.75\end{array}$ & $\begin{array}{l}0.70 \\
0.78\end{array}$ \\
\hline $362-29-4$ & $\begin{array}{l}\text { Marly nanno chalk, dusky to grayish yellow- } \\
\text { green; calcareous nannofossils } 50 \%-60 \% \text {, clay } \\
\text { minerals } 30 \%-40 \% \text {, pyrite } 2 \% \text {, traces of quartz } \\
\text { and tourmaline; coccospheres present }\end{array}$ & 1. & 6.29 & 52.42 & 0.66 \\
\hline $362-31-4$ & $\begin{array}{l}\text { Marly nanno chalk, greenish-gray ( } 5 \mathrm{GY} 6 / 1 \text { ); } \\
\text { composed of over } 70 \% \text { calcareous nannofossils, } \\
20 \% \text { clay minerals; Minor composents include } \\
\text { forams, pyrite, tourmaline, and dolomite rhombs }\end{array}$ & 1. & 8.62 & 71.83 & 0.40 \\
\hline $362-34-4$ & $\begin{array}{l}\text { Marly nannoplankton chalk, medium greenish- } \\
\text { gray ( } 5 \mathrm{GY} 5 / 1) \text {; composed of about equal } \\
\text { amounts of calcareous nannofossils and clay } \\
\text { minerals; contains foraminifera and traces of } \\
\text { quartz and heavy minerals }\end{array}$ & 1. & $\begin{array}{r}6.19 \\
-\quad\end{array}$ & 51.58 & 0.35 \\
\hline
\end{tabular}


TABLE 1 - Continued

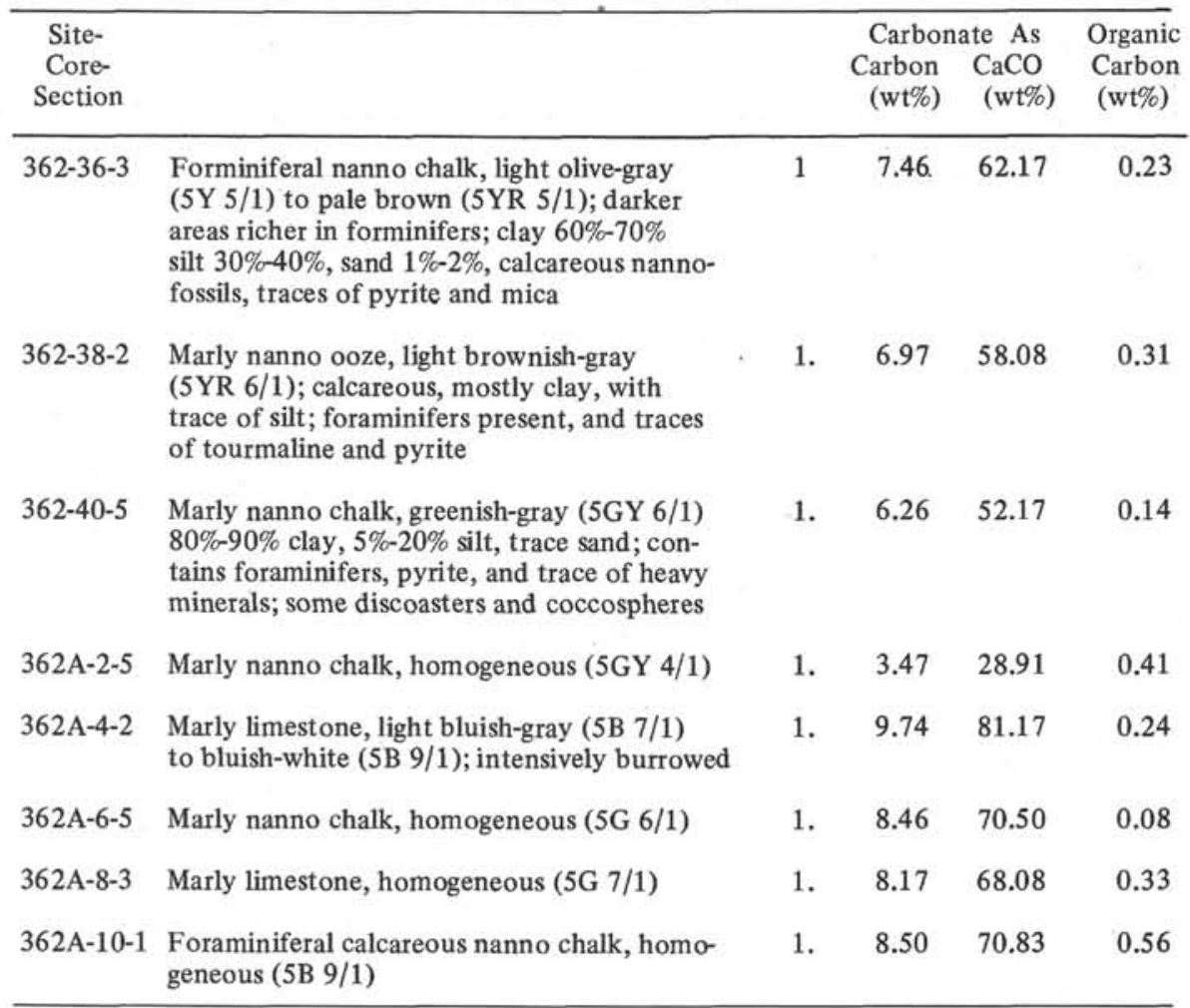

${ }^{\text {a}}$ Sample size insufficient for this determination.

The 15 cores obtained from Site 361 in the Cape Basin ranged in age from Eocene to Lower Cretaceous and in depth from 179.8 to 1222.0 meters. The sediment type ranged from marly nannofossil ooze, pelagic clays and shales to mudstones with varying amounts of sand. Carbonate carbon reported as calcium carbonate ranged from $76 \%$ in the nanno ooze to $1 \%$ to $20 \%$ in shales. The total organic content was relatively low for the Tertiary through the Upper Cretaceous ranging from $0.06 \%$ to $0.8 \%$ with an average of $0.40 \%$ as shown in Table 2. The Lower Cretaceous interval contained organic-rich sediments ranging in organic carbon content from a low of $1.76 \%$ to a high of $8.38 \%$ with an average of $4.04 \%$. Similarly, the lipid content was low in the Tertiary and Upper Cretaceous ranging from $0.001 \%$ to $0.006 \%$ of the total rock, whereas the lipid content was relatively high in the Lower Cretaceous ranging from $0.31 \%$ to $0.21 \%$.

The environment of deposition of this suite was marine as indicated by the carbon isotopic composition of the lipid fraction, $\delta \mathrm{C}^{13} \mathrm{PBD}=-28.7$ to -25.0 . A slight trend in these values with depth was observed. This trend may be indicative of advancing genesis with depth (temperature) or more likely a decrease in the terrestrial influence on the marine sediment. The $\delta \mathrm{C}^{13} \mathrm{PBD}-30$ value of several Lower Cretaceous kerogen samples reflects the large contribution of woody material present.

The ion exchangeable ammonia nitrogen as determined by the half Kjeldahl is relatively constant throughout the suite and averages $44.8 \mathrm{ppm}$. Total nitrogen, as determined by the full Kjeldâhl analysis, trends similarly to the organic carbon, that is, the lower
Cretaceous samples are richer in total nitrogen (average $1357 \mathrm{ppm}$ ) than the Tertiary and Upper Cretaceous samples (average $325 \mathrm{ppm}$ ). Most of the nitrogen in the Lower Cretaceous is found in the organic portion of these sediments.

The percentage of $\mathrm{C}, \mathrm{H}, \mathrm{N}, \mathrm{S}, \mathrm{O}$ of the lipid fraction was determined on the Lower Cretaceous cores from Site 361 . With the exception of sulfur, the values were relatively constant throughout the interval, as shown in Table 4 . In the case of sulfur, the values averaged 2.62 $\pm 1.2 \%$ for the Lower Cretaceous samples $361-29-5$ to $361-38-2$ and increased from $5.19 \%$ to $14.32 \%$ for the remaining Lower Cretaceous samples $361-40-3$ to 361 44-2.

The 25 frozen cores obtained from Sites 362 and $362 \mathrm{~A}$, located on the Abutment Plateau segment of the Walvis Ridge where it joins the continental margin of southwest Africa, range in age from.Pleistocene to Eocene and in depth from 43.3 meters to 1025.4 meters. The sediment type ranges from marly nanno ooze in the Pleistocene, to nanno chalk in the Miocene to marly limestone in the Eocene. Carbonate carbon reported as calcium carbonate is high in the entire section ranging from $30 \%$ to $81 \%$ with an average of 54.2 percent.

The sediments from Pleistocene $(43.3 \mathrm{~m}$ ) to Miocene (555.0 meters) were deposited in an open marine environment as determined by carbon isotopic compositions of the lipid fraction, $\delta C^{13} \mathrm{PDB}=-23.5$ \pm 0.7 . At greater depths, namely the Miocene sediments from 600.8 meters to the Eocene at 1025.4 meters, were derived from a more terrestrially influenced environment, $\delta \mathrm{C}^{13} \mathrm{PDB}=-26.2 \pm 0.5$. 
TABLE 2

Carbonate Content and Concentrations (wt $\%$ ) of Organic Matter in Geochemical Samples from DSDP Leg 40

\begin{tabular}{|c|c|c|c|c|c|c|c|c|}
\hline \multirow[b]{2}{*}{$\begin{array}{l}\text { Site-Core- } \\
\text { Section }\end{array}$} & \multirow[b]{2}{*}{$\begin{array}{l}\text { Geologic } \\
\text { Age }\end{array}$} & \multirow[b]{2}{*}{$\begin{array}{l}\text { Subbottom } \\
\text { Depth (m) }\end{array}$} & \multicolumn{2}{|c|}{ Carbonate } & \multicolumn{2}{|c|}{ Organic Carb. } & \multirow[b]{2}{*}{$\begin{array}{l}\text { Kerogen } \\
(w t \%)\end{array}$} & \multirow{2}{*}{$\begin{array}{l}\text { Total } \\
\text { Lipid }^{a} \\
\text { (wt\%) }\end{array}$} \\
\hline & & & $\begin{array}{l}\text { Carbon } \\
\text { (wt\%) }\end{array}$ & $\begin{array}{c}\mathrm{CaCO}_{3} \\
(\mathrm{wt} \%)\end{array}$ & $\begin{array}{l}\text { Total } \\
\text { (wt } \%)\end{array}$ & $\begin{array}{r}\text { Lipid } \\
\text { (wt\%) }\end{array}$ & & \\
\hline $361-5-4$ & Eocene & $179.8-180.0$ & 2.47 & 20.58 & 0.23 & 0.023 & 0.23 & 0.82 \\
\hline $361-8-5$ & Paleocene & $257.0-257.3$ & 9.19 & 76.58 & 0.20 & 0.002 & 0.20 & 0.88 \\
\hline $361-10-5$ & Paleocene & $276.3-276.5$ & $<0.10$ & $<0.83$ & 0.85 & 0.001 & 0.85 & 0.12 \\
\hline $361-12-4$ & Paleocene & $301.7-302.9$ & $<0.10$ & $<0.83$ & 0.39 & 0.002 & 0.39 & 0.49 \\
\hline $361-23-3$ & U. Cretaceous & $767.3-767.5$ & 0.19 & 1.58 & 0.45 & 0.003 & 0.45 & 0.65 \\
\hline $361-25-3$ & U. Cretaceous & $862.7-862.9$ & 0.31 & 2.58 & 0.14 & 0.001 & 0.14 & 0.81 \\
\hline $361-27-3$ & U. Cretaceous & $957.3-957.5$ & 0.25 & 2.08 & 0.87 & 0.006 & 0.86 & 0.71 \\
\hline $361-29-5$ & L. Cretaceous & $1036.3-1036.5$ & 0.18 & 1.50 & 5.62 & 0.080 & 5.54 & 1.41 \\
\hline $361-31-2$ & L. Cretaceous & $1050.8-1051.0$ & 0.72 & 6.00 & 3.69 & 0.050 & 3.64 & 1.36 \\
\hline $361-34-4$ & L. Cretaceous & $1082.4-1082.4$ & 1.10 & 9.17 & 8.38 & 0.214 & 8.17 & 2.55 \\
\hline $361-36-3$ & L. Cretaceous & $1099.8-1099.9$ & 2.48 & 20.67 & 1.76 & 0.041 & 1.72 & 2.33 \\
\hline $361-38-2$ & L. Cretaceous & $1117.4-1117.4$ & 2.59 & 21.58 & 2.54 & 0.031 & 2.51 & 1.21 \\
\hline $361-40-3$ & L. Cretaceous & $1147.4-1147.4$ & $<0.10$ & $<0.83$ & 3.68 & 0.057 & 3.62 & 1.54 \\
\hline $361-42-0$ & L. Cretaceous & $1181.0-1181.1$ & 0.20 & 1.67 & 4.23 & 0.079 & 4.15 & 1.88 \\
\hline $361-44-2$ & L. Cretaceous & $1221.8-1222.0$ & 0.13 & 1.08 & 2.38 & 0.053 & 2.33 & 2.22 \\
\hline $362-1-5$ & Pleistocene & $43.3-\quad 43.5$ & 4.24 & 35.33 & 4.75 & 0.028 & 4.72 & 0.60 \\
\hline $362-3-4$ & Pleistocene & $60.8-\quad 61.0$ & 4.00 & 33.33 & 4.42 & 0.044 & 4.38 & 0.99 \\
\hline $362-5-4$ & Pleistocene & $79.8-\quad 80.0$ & 3.85 & 32.08 & 5.28 & 0.064 & 5.22 & 1.21 \\
\hline $362-7-5$ & Pleistocene & $100.3-100.5$ & 4.38 & 36.50 & 3.39 & 0.058 & 3.33 & 1.70 \\
\hline $362-9-5$ & Pleistocene & $119.3-119.5$ & 5.02 & 41.83 & 3.12 & 0.052 & 3.07 & 1.65 \\
\hline $362-11-5$ & Pliocene & $138.3-138.5$ & 5.73 & 47.75 & 2.17 & 0.030 & 2.14 & 1.38 \\
\hline $362-13-4$ & Pliocene & $155.8-156.0$ & 4.89 & 40.75 & 2.88 & 0.050 & 2.83 & 1.74 \\
\hline $362-15-5$ & Miocene & $185.8-186.0$ & 5.63 & 46.92 & 2.43 & 0.031 & 2.40 & 1.29 \\
\hline $362-17-5$ & Miocene & $223.8-224.0$ & 7.14 & 59.50 & 1.01 & 0.009 & 1.00 & 0.93 \\
\hline $362-19-5$ & Miocene & $261.8-262.0$ & 6.60 & 55.00 & 1.27 & 0.022 & 1.25 & 1.73 \\
\hline $362-21-5$ & Miocene & $299.8-300.0$ & 8.51 & 70.92 & 1.48 & 0.006 & 1.47 & 0.41 \\
\hline $362-23-5$ & Miocene & $337.8-338.0$ & 8.45 & 70.42 & 0.73 & 0.010 & 0.72 & 1.43 \\
\hline $362-25-5$ & Miocene & $375.8-376.0$ & 8.29 & 69.08 & 0.73 & 0.018 & 0.71 & 2.42 \\
\hline $362-27-5$ & Miocene & $413.8-414.0$ & 6.40 & 53.29 & 0.81 & 0.011 & 0.79 & 1.41 \\
\hline $362-29-5$ & Miocene & $450.3-450.5$ & 6.00 & 50.00 & 0.63 & 0.009 & 0.62 & 1.38 \\
\hline $362-31-4$ & Miocene & $488.3-488.5$ & 8.28 & 69.00 & 0.35 & 0.004 & 0.35 & 1.12 \\
\hline $362-34-4$ & Miocene & $554.8-555.0$ & 6.81 & 56.75 & 0.48 & 0.004 & 0.48 & 0.76 \\
\hline $362-36-3$ & Miocene & $600.8-601.0$ & 7.08 & 59.00 & 0.20 & 0.003 & 0.20 & 1.28 \\
\hline $362-38-2$ & Miocene & $646.8-647.0$ & 6.74 & 56.17 & 0.34 & 0.001 & 0.34 & 0.22 \\
\hline $362-40-5$ & Miocene & $708.3-708.5$ & 6.65 & 55.42 & 0.27 & 0.001 & 0.27 & 0.48 \\
\hline $362 A-2-5$ & Oligocene & $803.2-803.4$ & 3.45 & 28.75 & 0.41 & 0.003 & 0.41 & 0.62 \\
\hline $362 \mathrm{~A}-4-2$ & Oligocene & $879.3-879.4$ & 9.75 & 81.25 & 0.24 & 0.001 & 0.24 & 0.56 \\
\hline $362 A-6-5$ & Oligocene & $936.4-936.5$ & 7.60 & 63.33 & 0.39 & 0.001 & 0.39 & 0.30 \\
\hline $362 A-8-3$ & Eocene & $971.3-971.4$ & 8.21 & 68.42 & 0.30 & 0.001 & 0.30 & 0.46 \\
\hline $362 \mathrm{~A}-10-1$ & Eocene & $1025.4-1025.4$ & 8.52 & 71.00 & 0.32 & 0.001 & 0.32 & 0.32 \\
\hline
\end{tabular}

${ }^{\mathrm{a}}$ As weight percent of organic carbon.

The interval from the Pleistocene to the Miocene at 186 meters contains organic-rich sediments averaging 3.55 percent organic carbon. The fresh cut sections also possessed a petroliferous odor. The Mrocene sediments from Sections $362-17-5$ to $362-29-5$ average 0.92 $\pm 0.32 \%$ organic carbon. The remaining sediments from Miocene Section 362-31-4 to Eocene Section 362A-10-1 have less organic carbon, averaging $0.33 \pm 0.08 \%$. The amount of lipid carbon follows the same trend as the organic carbon.

Organic detritus deposited in aquatic environments contains a large amount of ammonic nitrogen. Part of this nitrogen is eliminated as ammonia and part is fixed in condensed aromatic rings in the kerogen. In this suite of samples, the ion-exchangeable ammonia nitrogen content is relatively constant, averaging $135.5 \mathrm{ppm}$, but somewhat higher than the suite from Site 361, which averaged $44.8 \mathrm{ppm}$. The total nitrogen, on the other hand. varies with depth from an average of $2490 \mathrm{ppm}$ for Sections 362-1-5 to $362-19-5$ to an average of 473 ppm for Sections 362-21-5 to 362A-10-1.

The percentage of $\mathrm{C}, \mathrm{H}, \mathrm{N}, \mathrm{S}, \mathrm{O}$ of the lipid fraction could be determined on the Pleistocene through the Miocene Section 362-15-2. These values were relatively constant with no trends with depths as shown in Table 4. However, the hydrogen to carbon ratio for this suite of samples averaged 1.77, which was higher than samples of the Lower Cretaceous from Site 361 which averaged 1.39. Thus the degree of catagenesis has not progressed as far in the Pleistocene to Miocene samples of Site 362 as in the Lower Cretaceous samples of Site 361 .

\section{CONCLUSION}

In the Cape Basin, the Lower Cretaceous samples contain numerous components of a shallow-water deltaic environment with abundant terrestrial organic matter redeposited in a type of proximal fan to fan- 
TABLE 3

Carbon Isotopic Composition of Lipid and Kerogen Fractions in Geochemical Samples From DSDP Leg 40

\begin{tabular}{l|rrr}
\hline \multirow{2}{*}{ Site-Core } & \multicolumn{3}{|c}{ Carbon Isotopic Composition } \\
\cline { 2 - 4 } Section & Lipid & Kerogen & L-K \\
\hline $361-5-4$ & -27.9 & -25.9 & -2.0 \\
$361-8-5$ & -26.7 & -25.3 & -1.4 \\
$361-10-5$ & -27.8 & -25.7 & -2.1 \\
$361-12-4$ & -26.8 & -26.2 & -0.6 \\
$361-23-3$ & -27.4 & -27.6 & 0.2 \\
$361-25-3$ & -27.3 & -27.1 & -.2 \\
$361-27-3$ & -23.6 & -28.7 & 5.1 \\
$361-29-5$ & -28.0 & -28.7 & 0.7 \\
$361-31-2$ & -26.4 & -25.4 & -1.0 \\
$361-34-4$ & -28.2 & -27.0 & -1.2 \\
$361-36-3$ & -26.6 & -30.8 & 4.2 \\
$361-38-2$ & -26.2 & -28.4 & 2.2 \\
$361-40-3$ & -26.0 & -25.9 & -0.1 \\
$361-42-0$ & -27.4 & -26.9 & -0.5 \\
$361-44-2$ & -25.0 & -30.4 & 5.4 \\
$362-1-5$ & -23.1 & -21.0 & -2.1 \\
$362-3-4$ & -23.5 & -22.8 & -0.7 \\
$362-5-4$ & -23.7 & -21.1 & -2.6 \\
$362-7-5$ & -23.6 & -22.3 & -1.3 \\
$362-9-5$ & -23.6 & -22.5 & -1.1 \\
$362-11-5$ & -23.1 & -23.6 & 0.5 \\
$362-13-4$ & -22.9 & -20.6 & -2.3 \\
$362-15-5$ & -22.4 & -19.6 & -2.8 \\
$362-17-5$ & -23.0 & -22.6 & -0.4 \\
$362-19-5$ & -24.2 & -23.6 & -0.6 \\
$362-21-5$ & -23.6 & -21.5 & -2.1 \\
$362-23-5$ & -23.0 & -22.1 & -0.9 \\
$362-25-5$ & -23.6 & -24.5 & 0.9 \\
$362-27-5$ & -25.5 & -27.3 & 1.8 \\
$362-29-5$ & -23.1 & -26.6 & 3.5 \\
$362-31-4$ & -24.3 & -29.2 & 4.9 \\
$362-34-4$ & -24.6 & -25.4 & 0.8 \\
$362-36-3$ & -26.2 & $a$ & \\
$362-38-2$ & -26.0 & -23.8 & -2.2 \\
$362-40-5$ & -25.4 & -31.6 & 6.2 \\
$362-2-5$ & -27.1 & -23.0 & -4.1 \\
$362-4-2$ & -26.3 & -34.8 & 8.5 \\
$362-6-5$ & -26.0 & -21.4 & -4.6 \\
$362-8-3$ & -26.8 & -33.0 & 6.2 \\
$362-10-1$ & -26.4 & -21.8 & -4.6 \\
\hline a Sample insufficient & or unsuitable for \\
this determination. & & \\
& & &
\end{tabular}

valley environment. The petroleum (soluble lipid) in the Lower Cretaceous sediments is five times more abundant than in the younger pelagic clays and carbonates. As the corridor between continents widened, the influx of organic matter and in particular terrestrial organic matter decreased to the point where in most cases insufficient organic matter is present for advanced genesis of petroleum. Thus the Lower Cretaceous is more conducive to petroleum genesis because of (a) a high concentration of organic matter and (b) increased temperature. However, sufficient temperatures to produce migratable amounts of petroleum have not been attained.

The Walvis Ridge was a shallow feature created between the South American and African continents and has gradually subsided to its present depth with no indication of further uplift during its history. The influx of organic matter in its early history was light and contained a substantial terrestrial contribution as
TABLE 4

Normalized Percent Composition of Carbon, Hydrogen, Nitrogen, and Sulfur in the Lipid Fraction of Geochemical Samples From Leg 40

\begin{tabular}{|c|c|c|c|c|c|c|}
\hline $\begin{array}{l}\text { Site-Core- } \\
\text { Section }\end{array}$ & $\mathrm{C}$ & $\mathrm{H}$ & $\mathrm{N}$ & $\mathrm{S}$ & $\mathrm{O}^{\mathrm{a}}$ & $\mathrm{H} / \mathrm{C}$ \\
\hline \multicolumn{7}{|c|}{ Cape Basin Site 361} \\
\hline $\begin{array}{l}361-29-5 \\
361-31-2 \\
361-34-4 \\
361-36-3 \\
361-38-2 \\
361-40-3 \\
361-42-0 \\
361-44-2 \\
\text { Average }\end{array}$ & $\begin{array}{l}82.13 \\
82.79 \\
80.34 \\
82.39 \\
82.37 \\
79.41 \\
81.01 \\
72.52 \\
80.37\end{array}$ & $\begin{array}{r}10.19 \\
9.79 \\
10.17 \\
9.67 \\
8.95 \\
9.00 \\
9.99 \\
9.68 \\
9.41\end{array}$ & $\begin{array}{l}0.47 \\
0.35 \\
0.66 \\
0.44 \\
0.72 \\
0.68 \\
0.37 \\
0.56 \\
0.53\end{array}$ & $\begin{array}{r}2.90 \\
1.97 \\
3.84 \\
2.51 \\
1.87 \\
5.19 \\
8.00 \\
14.32 \\
5.08\end{array}$ & $\begin{array}{c}4.31 \\
5.10 \\
4.99 \\
4.99 \\
6.09 \\
5.72 \\
0.63 \\
5.06 \\
4.61\end{array}$ & $\begin{array}{l}1.48 \\
1.41 \\
1.51 \\
1.40 \\
1.29 \\
1.35 \\
1.35 \\
1.59 \\
1.39\end{array}$ \\
\hline \multicolumn{7}{|c|}{ Walvis Ridge Site 362} \\
\hline $\begin{array}{l}362-1-5 \\
362-3-4 \\
362-5-4 \\
362-7-5 \\
362-9-5 \\
362-11-5 \\
362-13-4 \\
362-15-5 \\
\text { Average }\end{array}$ & $\begin{array}{l}79.45 \\
79.32 \\
76.74 \\
78.39 \\
75.58 \\
81.35 \\
77.35 \\
77.22 \\
78.18\end{array}$ & $\begin{array}{l}11.53 \\
11.91 \\
11.92 \\
11.77 \\
10.92 \\
12.21 \\
11.40 \\
11.46 \\
11.64\end{array}$ & $\begin{array}{l}0.60 \\
0.36 \\
0.46 \\
0.35 \\
1.13 \\
0.28 \\
0.84 \\
0.55 \\
0.57\end{array}$ & $\begin{array}{l}1.68 \\
7.56 \\
4.06 \\
3.61 \\
2.41 \\
4.13 \\
1.63 \\
1.96 \\
3.38\end{array}$ & $\begin{array}{l}6.74 \\
0.85 \\
6.82 \\
5.88 \\
9.96 \\
2.03 \\
8.78 \\
8.81 \\
6.23\end{array}$ & $\begin{array}{l}1.73 \\
1.79 \\
1.89 \\
1.79 \\
1.72 \\
1.79 \\
1.75 \\
1.77 \\
1.77\end{array}$ \\
\hline
\end{tabular}

axygen determined by difference.

TABLE 5

Ammonia and Total Nitrogen Content as Determined by the Half and Full Kjeldalh for Geochemical Samples From DSDP Leg 40

\begin{tabular}{lrr}
\hline $\begin{array}{c}\text { Site-Core- } \\
\text { Section }\end{array}$ & \multicolumn{2}{c}{ Kjeldalh (PPM) } \\
& \multicolumn{1}{c}{ Full } \\
\hline $361-5-4$ & 19 & 300 \\
$361-8-5$ & 23 & 200 \\
$361-10-5$ & 37 & 300 \\
$361-12-4$ & 34 & 300 \\
$361-23-3$ & 56 & 500 \\
$361-25-3$ & 23 & 400 \\
$361-27-3$ & 69 & 500 \\
$361-29-5$ & 80 & 100 \\
$361-31-2$ & 46 & 1400 \\
$361-34-4$ & 72 & 3200 \\
$361-36-3$ & 54 & 1000 \\
$361-38-2$ & 25 & 900 \\
$361-40-3$ & 68 & 1400 \\
$361-42-0$ & 66 & 600 \\
$361-44-2$ & 39 & 1000 \\
$362-1-5$ & 149 & 3500 \\
$362-3-4$ & 54 & 3600 \\
$362-5-4$ & 71 & 3800 \\
$362-7-5$ & 226 & 3000 \\
$362-9-5$ & 321 & 2300 \\
$362-11-5$ & 175 & 2000 \\
$362-13-4$ & 324 & 2300 \\
$362-15-5$ & 200 & 2100 \\
$362-17-5$ & 179 & 1000 \\
$362-19-5$ & 162 & 1300 \\
$362-21-5$ & 130 & 900 \\
$362-23-5$ & 128 & 800 \\
$362-25-5$ & 100 & 800 \\
$362-27-5$ & 150 & 100 \\
$362-29-5$ & 144 & 900 \\
$362-31-4$ & 71 & 500 \\
$362-34-4$ & 88 & 600 \\
\hline & & \\
\hline
\end{tabular}


TABLE 5 - Continued

\begin{tabular}{|c|c|c|}
\hline $\begin{array}{l}\text { Site-Core- } \\
\text { Section }\end{array}$ & $\begin{array}{l}\text { Kjeldalh } \\
\text { Hale }\end{array}$ & $\begin{array}{c}\text { (PPM) } \\
\text { Full }\end{array}$ \\
\hline $362-36-3$ & 22 & 300 \\
\hline $362-38-2$ & 71 & 300 \\
\hline $362-40-5$ & 52 & 400 \\
\hline $362 A-2-5$ & 72 & 600 \\
\hline $362 A-4-2$ & 21 & 200 \\
\hline $362 A-6-5$ & 190 & 300 \\
\hline $362 \mathrm{~A}-8-3$ & 156 & 200 \\
\hline $362 \mathrm{~A}-10-1$ & 132 & 200 \\
\hline
\end{tabular}

indicated by the carbon isotopic composition of the lipid fraction of these sediments. The influx of organic matter increased and the terrestrial influence decreased as the current circulation patterns became established in the South Atlantic. The sediments became organic rich and predominantly pelagic. Petroleum genesis is in an early stage in the upper sections of these sediments and conditions are unfavorable for development of migratable quantities of petroleum in the lower sections due to the lack of organic matter. 